\section{To: (Receiving organization) \\ W Root \\ Hanford Tanks Initiative}

5. Proj./Prog./Dept./Div.:

Waste Management

8. originator Renarks:

Transmittal of document for information and release to HTI project files. 11. Receiver Renarks: 11A. Design Baseline Document? [] Yes [X] Ho

3. From: (originating Organization)
Numatec Hanford Co., Project
Definition
6. Design Authority/ Design Agent/Cog.
Engr:
DF Iwatate

3. From: (originating organization) Numatec Hanford Co., Project 6. Design Authority/ Design Agent/Cog.

DF Iwatate
4. Related EDT No.:

$N / A$

7. Purchase Order No.:

$N / A$

9. Equip./Component No.: $N / A$

10. System/Bldg./Facility: N/A

12. Major Assm. Dwg. No.: N/A

13. Permit/Permit Application No.: $N / A$

14. Required Response Date: $N / A$

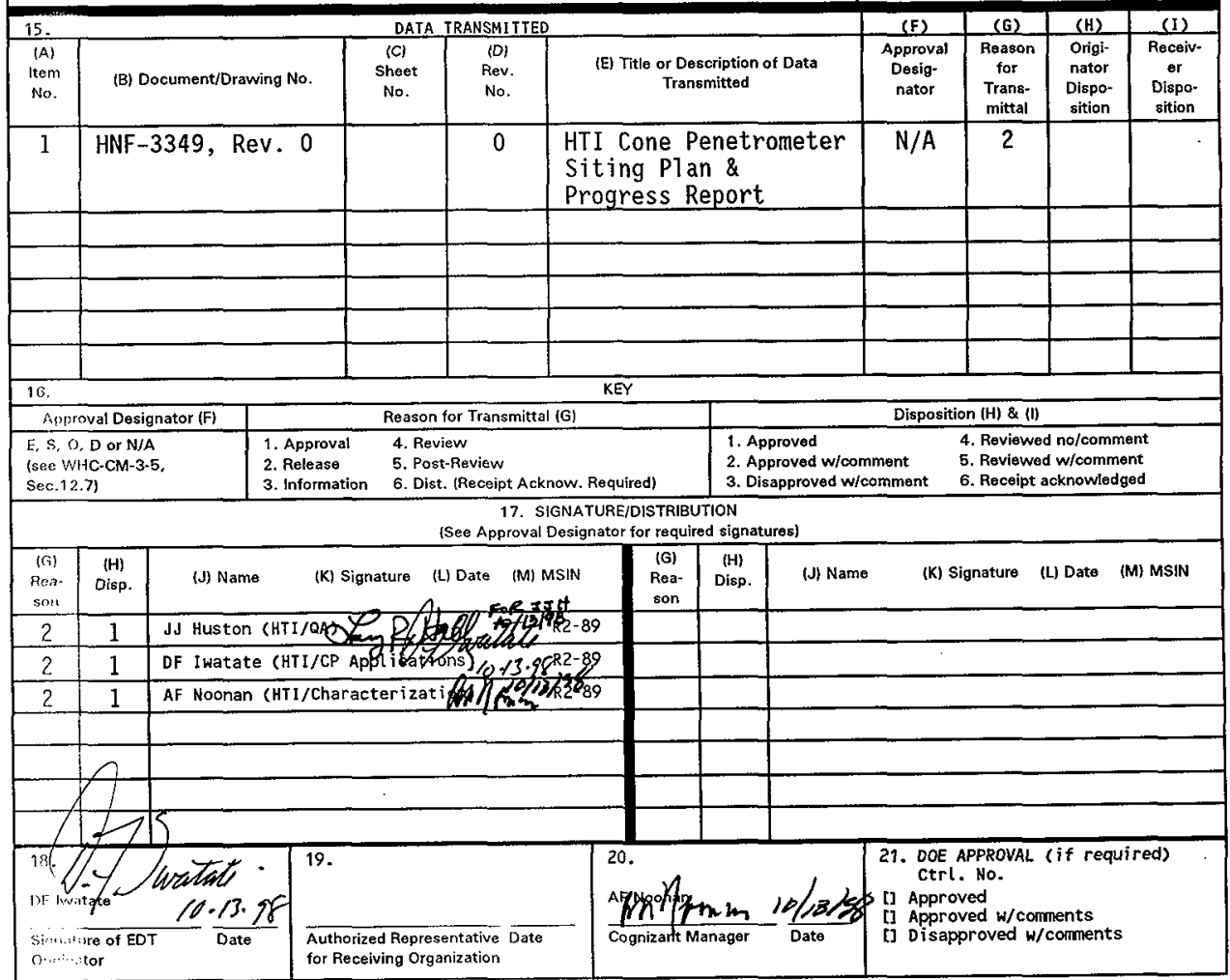




\title{
Hanford Tanks Initiative Cone Penetrometer Siting Plan and Progress Report
}

\author{
D. F. Iwatate
}

Numatec Hanford Company, Richland, WA 99352

U.S. Department of Energy Contract DE-AC06-96RL13200

\author{
EDT/ECN: 624541 \\ UC: 2030 \\ Org Code: 73500 \\ CAN: 103262 (CP Probe Deploy Prep) \\ B\&R Code: EW3130010 \\ Total Pages: 32
}

Key Words: Single-Shell Tanks, waste, leakage plume, cone penetrometer, gamma, xray fluorescence, vadose zone, soil, soil sampling, $A X-104$, training, siting $\mathrm{plan}$

Abstract: The HTI subsurface characterization task will use the Hanford Cone Penetrometer platform (CPP) to deploy soil sensor and sampling probes into the vadose zone/soils around AX-104 during FY-99. This Siting Plan describes activities and actions undertaken in support of CPP deployment: deployment goals, maps of the deployment sites/locations, pre-activity (siting-related) documentation tasks, a summary of activities that have been completed to date, and an estimated schedule of additional planned activities.

TRADEMARK DISCLAIMER. Reference herein to any specific comercial product, process, or service by trade name, trademark, manufacturer, or otherwise, does not necessarily constitute or imply its endorsement, recommendation, or favoring by the United States Government or any agency thereof or its contractors or subcontractors.

Printed in the United States of America. To obtain copies of this document, contact: Document Control Services, P.O. Box 950, Mailstop H6-08, Richland WA 99352, Phone (50́) 372-2420;

Fax (509) 376-4989.
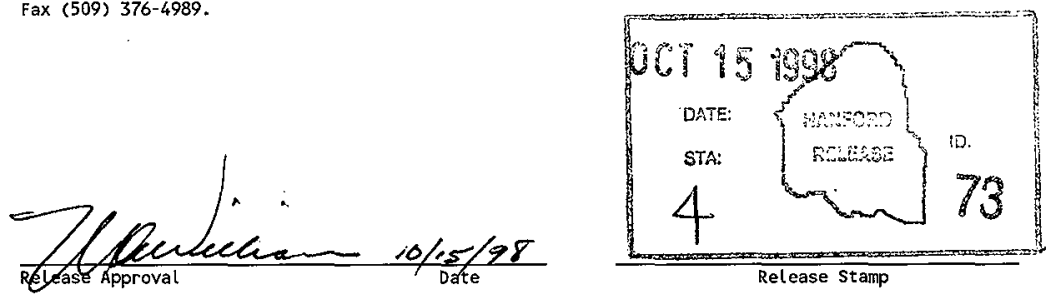
Rev. 0

ES-RPT-001

Rev. 0

\title{
Cone Penetrometer Siting Plan and \\ Progress Report
}

\author{
August 5, 1998
}




\section{CONE PENETROMETER SITING PLAN AND PROGRESS REPORT}

August 5, 1998

Waste Management Federal Services, Inc., Northwest Operations Richland, Washington 


\section{CONTENTS}

1.0 SCOPE

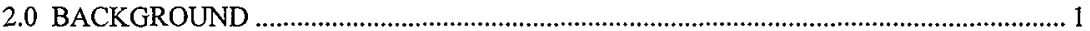

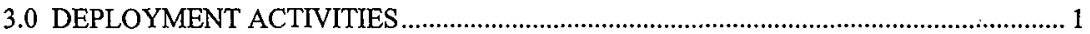

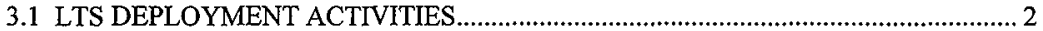

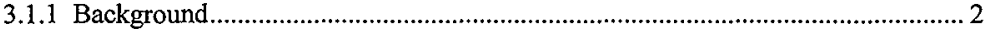

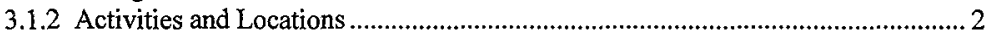

3.1.3 Additional Planned Activities.......................................................................... 9

3.2 ILAWDC DEPLOYMENT ACTIVITIES ………................................................... 10

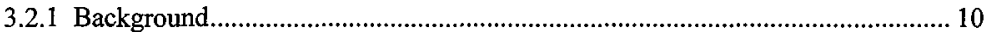

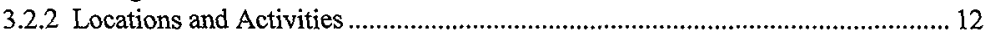

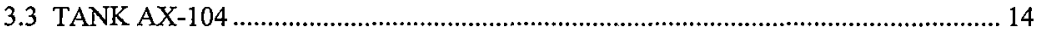

3.3.1 Background ..................................................................................................... 14

3.3.2 Locations and Activities ................................................................................. 14

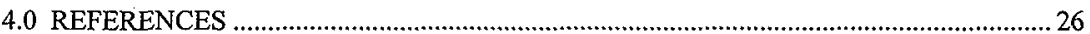

\section{LIST OF FIGURES}

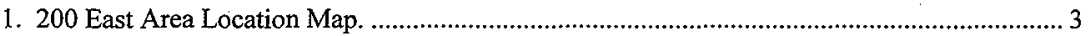

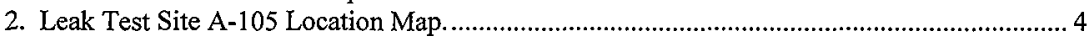

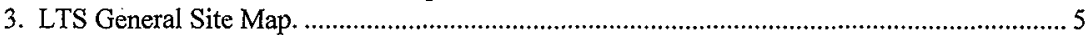

4. Ground Penetrating Radar Survey of Leak Test Site Push Sites................................................ 7

5. Immobilized Low Activity Waste Disposal Complex Well Map............................................... 11

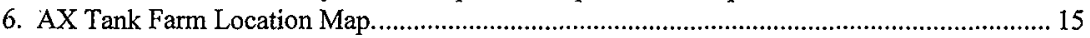

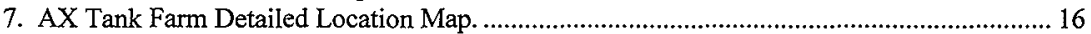

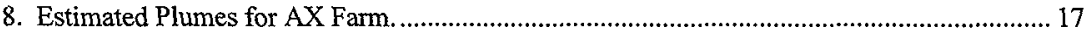

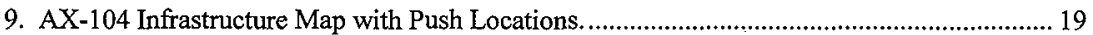

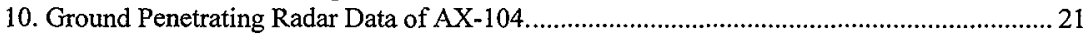

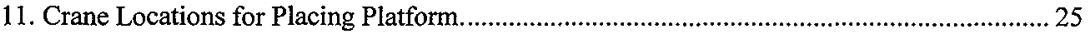

\section{LIST OF TABLES}

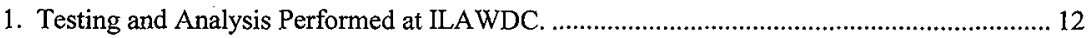

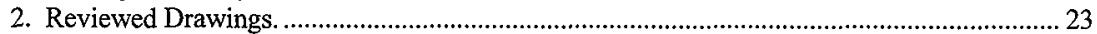




\section{LIST OF TERMS}

$\begin{array}{ll}\text { BLS } & \text { below land surface } \\ \text { CP } & \text { Cone Penetrometer } \\ \text { CPP } & \text { Cone Penetrometer Platform } \\ \text { DOE } & \text { U.S. Department of Energy } \\ \text { Ecology } & \text { Washington State Department of Ecology } \\ \text { GPR } & \text { Ground Penetrating Radar } \\ \text { GPS } & \text { Global Positioning System } \\ \text { HPGe } & \text { High Purity Germanium } \\ \text { HTI } & \text { Hanford Tank Farms Initiative } \\ \text { ILAWDC } & \text { Immobilized Low Activity Waste Disposal Complex } \\ \text { LTS } & \text { Leak Test Site } \\ \text { M/I } & \text { magnetometer/inclinometer } \\ \text { MSP } & \text { Multi Sensor Probe } \\ \text { SSP } & \text { Soil Sampling Probe } \\ \text { SWP } & \text { Special Work Permit } \\ \text { WAC } & \text { Washington Administrative Code } \\ \text { WCP } & \text { Work Control Package } \\ \text { WMNW } & \text { Waste Management Federal Services, Inc., Northwest Operations }\end{array}$




\section{ES-RPT-001 Rev. 0}

\section{CONE PENETROMETER SITING PLAN AND PROGRESS REPORT}

\subsection{SCOPE}

This report describes the activities and actions being undertaken to support deployment of the Cone Penetrometer Platform (CPP) in 200 East Area. The overall deployment activities will consist of three phases, which will be performed at the following locations:

- A-105 Mock Tank Leak Test Site (LTS).

- Immobilized Low Activity Waste Disposal Complex (ILAWDC).

- East AX Tank Farm adjacent to tank AX-104.

This report discusses and provides background information, deployment goals, maps of the sites, descriptions of the activities which are planned during the deployments, pre-activity documentation efforts, a brief listing of activities to date, and an estimated schedule of additional planned activities.

\subsection{BACKGROUND}

The CPP is a skid-mounted, adjustable hydraulic leg supported, platform designed and built specifically for deployment inside of the Hanford tank farms. Original platform design goals were to provide a hydraulic driven instrumented push rod for in-situ tank waste measurement and characterization. The initial design goal intended the platform to be deployed over the top of tanks for sampling through the tank riser assemblies. The present planned usage for the CPP is for interrogation of soils in areas surrounding the tanks. Deployment of the platform in AX tank farm is scheduled for early FY 1999.

\subsection{DEPLOYMENT ACTIVITIES}

In general, the goals of this task are to provide a demonstration of the soil sampling and characterization capabilities of the platform in the difficult working environment of the Hanford tank farms. During the tank farm deployment the platform will only interrogate soils surrounding and below the tank constructions, and for this type of investigation a new instrument configuration and soil sampling system have been developed to replace the in-tank system. New CPP instrumentation probes, the Multi Sensor Probe (MSP) and the multi-sample soil sampling probe (SSP) have been specifically designed and procured to support characterization and sampling of soils. The planned deployments provide opportunities at differing locations to refine, test and demonstrate the capabilities of the MSP and SSP technology: 
- $\quad$ LTS: Scheduled from January, 1998 to August 4, 1998. At LTS, the primary goal of the deployment is to provide an opportunity for operational testing of the platform, training of personnel, and to provide an opportunity for procedure testing and development. Additionally, the recently developed sensors and samplers will be tested and modified as needed to provide optimum performance

- ILAWDC: Scheduled from August 4, 1998 to December 31, 1998. At the ILAWDC site, additional SSP and MSP testing, design refinement, and acceptance verification will be conducted. The MSP instrumentation responses and SSP recovered soil samples will be compared to samples and data gathered during a recently completed conventional characterization effort. This comparison will be utilized to produce a verifiable and defensible grouting decision strategy procedure and to provide a field verification of the working condition of the MSP and SSP probes. Additionally, the operational condition of the magnetometer and inclinometer instrumentation that is included in the probe package will be demonstrated. A full-scale trial run utilizing all of the operational procedures and contamination control requirements will also be conducted during this deployment phase.

- Tank AX-104: Deployment to begin January 7, 1999. The AX-104 deployment is the operational demonstration of the applicability of the CPP technology to the difficult task of safe and cost-effective characterization operation within the tank farm boundaries.

\subsection{LTS DEPLOYMENT ACTIVITIES}

\subsubsection{Background}

The LTS is located inside of the 200 East Area north of Seventh Avenue and the 218-C-9 Burial Ground (see Figures 1 and 2). This is an uncontaminated area that has been utilized for several other demonstration activities in the recent past and is easily accessed from Seventh Avenue. The necessary environmental, ecological, biological, subsurface Ground Penetrating Radar (GPR) information, Site Specific Safety Plan and available site document reviews were completed in December of 1997 prior to the initial LTS activities. This documentation was required as a portion of Hanford Site work practice controls.

\subsubsection{Activities and Locations}

Three sites adjacent to the A-105 mock tank in the 200 East Area were selected and prepared for the deployment activities (see Figure 3 and 4 for Site Map and GPR results). A series of operational activities were planned for this set of deployments. The activities were designed to provide the necessary opportunities to test and develop the readiness of the equipment and the platform, develop the operational procedures, and support the training of 
ES-RPT-001 Rev. 0

Figure 1. 200 East Area Location Map.

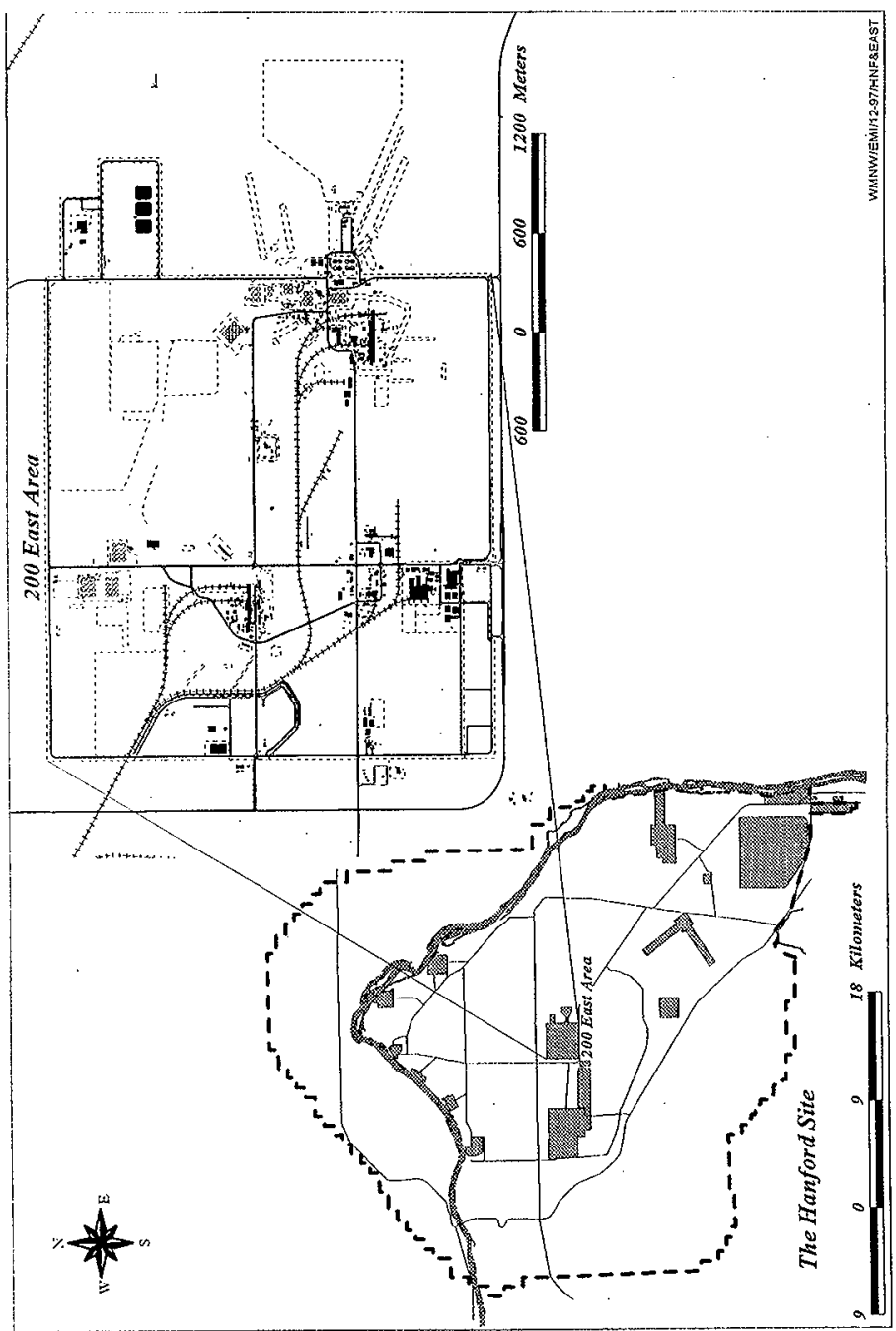


ES-RPT-001 Rev. 0

Figure 2. Leak Test Site A-105 Location Map.

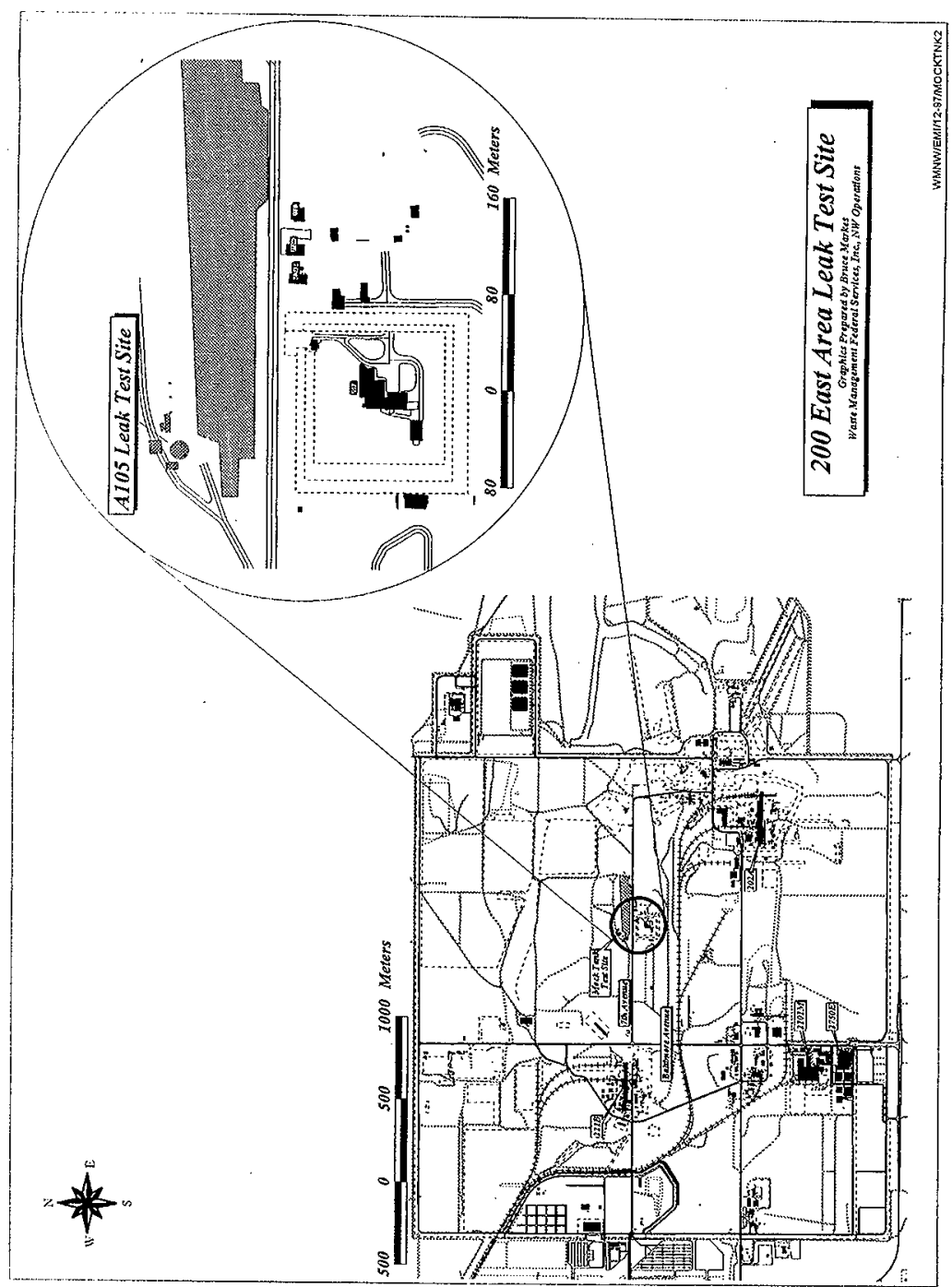


Figure 3. LTS General Site Map.

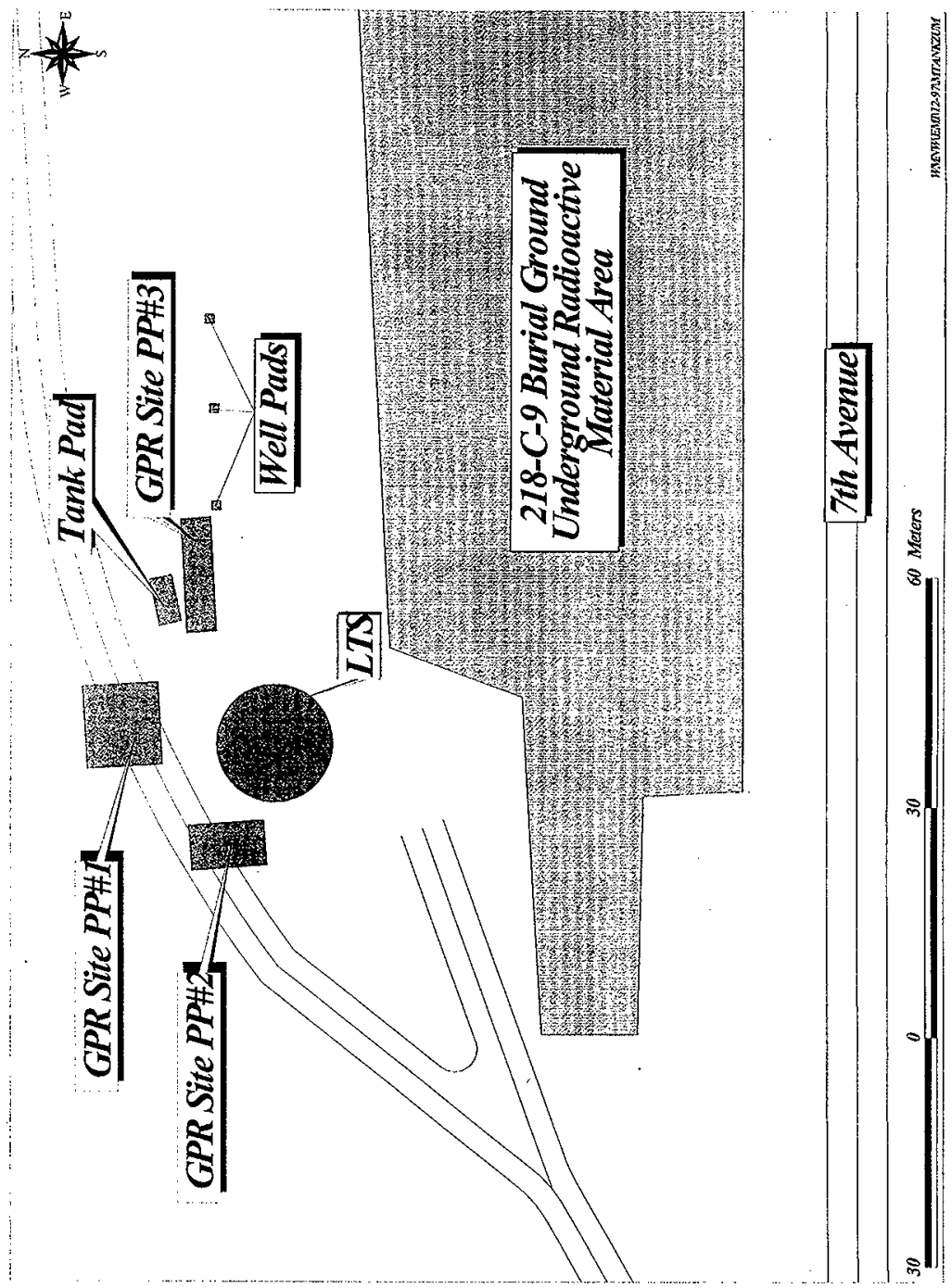


ES-RPT-001 Rev. 0

Rev. 0

This page intentionally left blank. 


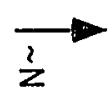

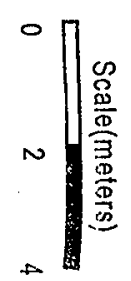
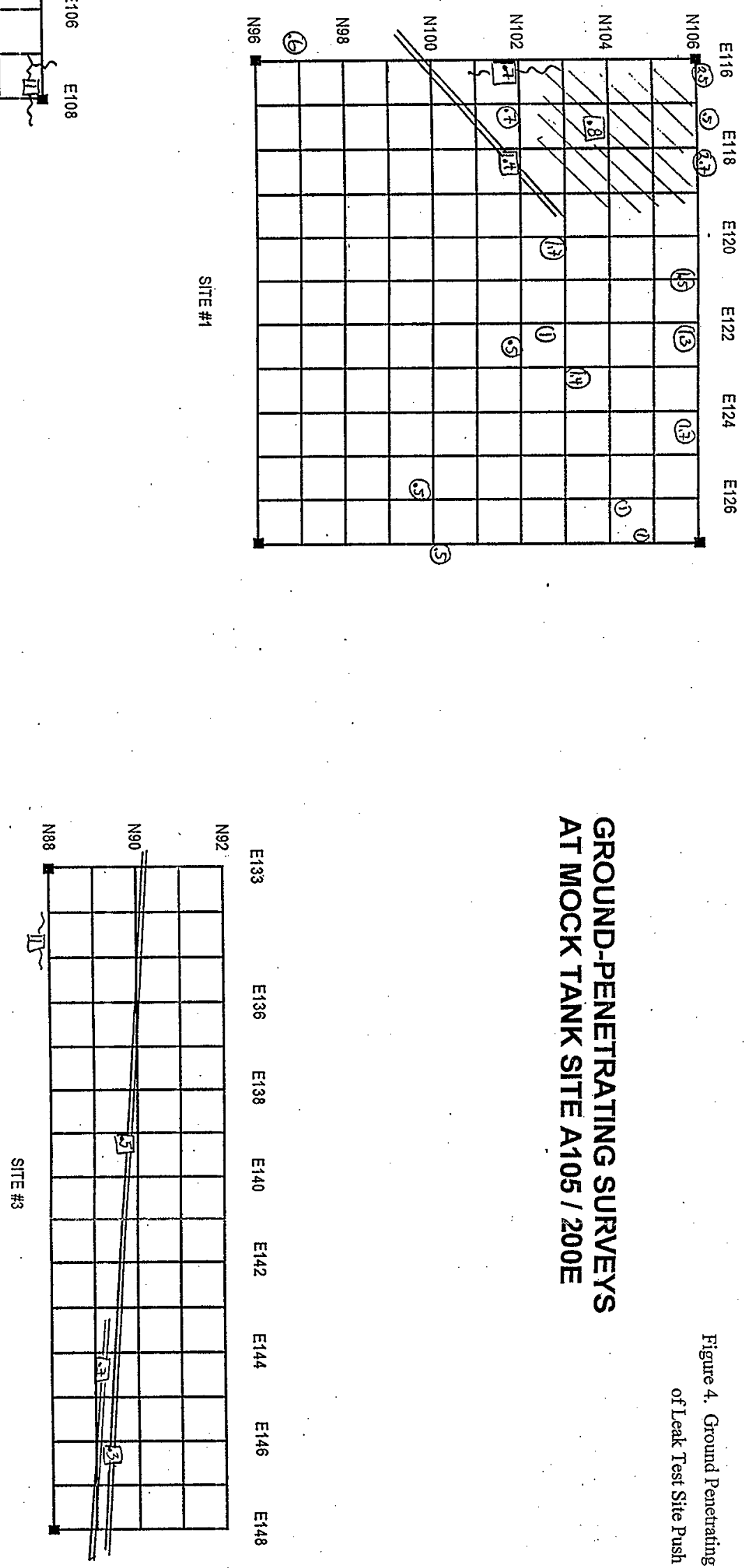

畩 
personnel to the operational guidelines. Only two of the three sites have been utilized during the activities at LTS. To date, July 24, 1998, only Sites 1 and 2 have been utilized for push operations.

The platform and associated support equipment were transported to the LTS area in mid-January and plans are to mobilize off of the location on August 4, 1998. Following is a list of the types of testing and development activities which have occurred, and the time frame for remaining testing at this location.

- Platform operational testing and cycling.

- Demonstrations of crane and rigging procedure implementation, including development of the procedure to accurately place/position the platform as a crane positioning activity, and site specific testing of the ability of the platform to accommodate uneven terrain.

- Multiple cone penetrometer (CP) pushes to various depths to train the technical staff under the supervision of the platform design and construction contractor.

- Training of support personnel for rod handling, waste control, decontamination procedure implementation, and sample probe handling and operation.

- Training of personnel for platform operations and integration of tank farm and Hanford Site personnel into a CPP team.

- Design, testing and operational demonstration of the grouting equipment.

- Operational procedure testing of the onboard instrument system.

- SSP retrieval system operation and system design modifications.

- Magnetometer/Inclinometer (M/I) probe testing and operation.

- $\quad$ Procedure refinement.

\subsubsection{Additional Planned Activities}

During the week of July 27 through July 31 several additional activities are planned. They are:

- Completion of the Acceptance Test Plan for the grouting modules, and final approval and crew training for the grouting procedures.

- Testing of the pipe cleaning and contamination control equipment (contingent on arrival of a redesigned plastic containment bag). 
ES-RPT-001 Rev. 0

- Clean up and readiness preparation for the deployment to ILAWDC.

\subsection{ILAWDC DEPLOYMENT ACTIVITIES}

\subsubsection{Background}

The ILAWDC Site has been selected for the second phase of CPP deployment because of the high level of characterization efforts that have been conducted. (Figure 5 provides the location of wells B8500, B8501 and B8502 drilled in support of the ILAWDC project.) The purpose of this deployment is to provide CPP collected data from the MSP and SSP equipment (e.g. gamma scintillation, neutron moisture probe, soil sampling, and tip resistance and sleeve friction devices) for comparison to the data gathered from the characterization efforts at this site. For details of the activities that were undertaken for the ILAWDC project see Characterization Plan for the Immobilized Low-Activity Waste Borehole, PNNL-11802. The types of physical analysis performed on samples retrieved for the ILAWDC project are listed in Table 1. At this site, the ILAWDC Characterization Plan called for collection and analysis of a continuous set of soil samples from 0 to 50 below land surface (BLS) for all three borings. In the one boring that penetrated deeper than $50 \mathrm{ft}$ (B8500), sampling below $50 \mathrm{BLS}$ was interval specific. In addition to the laboratory analysis performed on the samples retrieved, the wells were geophysically logged with a High Purity Germanium (HPGe) logging tool and a formation (neutron) moisture tool at the conclusion of the drilling and sampling process. This geophysical data will also be utilized for comparison purposes with the CPP derived data. 
Figure 5. Immobilized Low Activity Waste Disposal Complex Well Map.

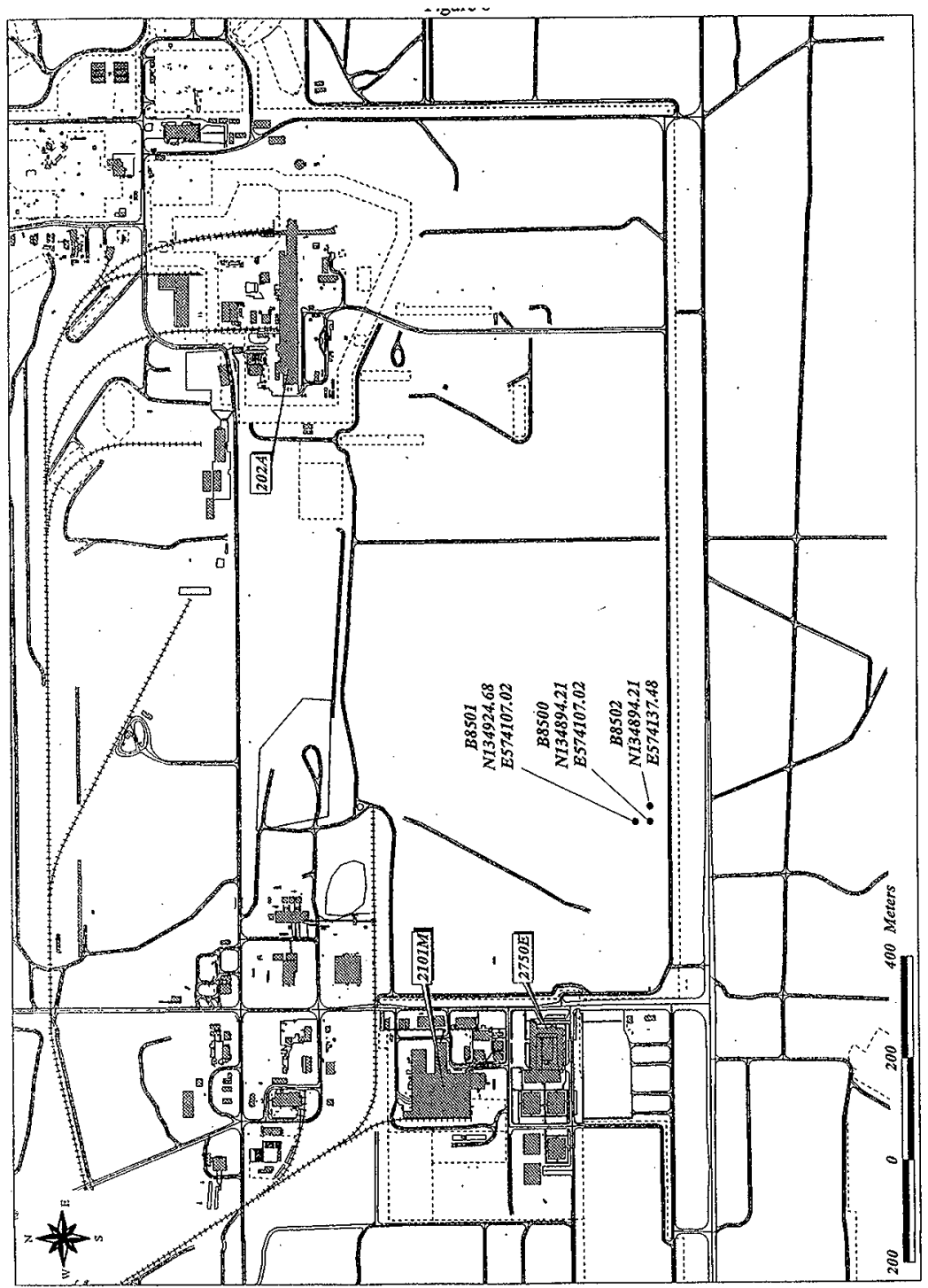


Table 1. Testing and Analysis Performed at ILAWDC.

\begin{tabular}{|c|c|c|c|c|}
\hline Test & $\begin{array}{l}\text { Chemical } \\
\text { Transport } \\
\text { Studies }{ }^{1} \\
\end{array}$ & $\begin{array}{l}\text { Physical Properties } \\
\text { of Vadose Zone }{ }^{2}\end{array}$ & $\begin{array}{c}\text { Estimating Recharge } \\
\text { by Environmental } \\
\text { Tracers }{ }^{3} \\
\end{array}$ & $\begin{array}{c}\text { Aquifer } \\
\text { Characterization }^{4}\end{array}$ \\
\hline Stratigraphy & $\mathrm{X}$ & $\mathrm{X}$ & $\mathrm{X}$ & $\mathrm{X}$ \\
\hline Geophysical logging & $\mathrm{X}$ & $\mathrm{X}$ & $\mathrm{X}$ & $\mathrm{X}$ \\
\hline Moisture content & $\mathrm{X}$ & $\mathrm{X}$ & $\mathrm{X}$ & \\
\hline Matric potential & & $\mathrm{X}$ & & \\
\hline $\mathrm{pH}$ & $\mathrm{X}$ & & & \\
\hline Cation exchange capability & $\mathrm{X}$ & & & \\
\hline Iron oxide concentration & $\mathrm{X}$ & & & \\
\hline Mineralogy - XRD & $\mathrm{X}$ & $\mathrm{X}$ & & \\
\hline Cations & $\mathrm{X}$ & & & \\
\hline Anions & $\mathrm{X}$ & & & \\
\hline $\mathrm{CaCO}_{3}$ & $\mathrm{X}$ & & $\mathrm{X}$ & \\
\hline Gravimetric moisture & $\mathrm{X}$ & $\mathrm{X}$ & $\mathrm{x}$ & \\
\hline Bulk density & $\mathrm{X}$ & $\mathrm{X}$ & $\mathrm{X}$ & $\mathrm{x}$ \\
\hline Particle density & $\mathrm{X}$ & $\mathrm{X}$ & $\mathrm{X}$ & \\
\hline Particle size & $\mathrm{X}$ & $\mathrm{X}$ & $\mathrm{X}$ & $\mathrm{X}$ \\
\hline Initial Porosity & & $\mathrm{X}$ & $\mathrm{X}$ & $\mathrm{X}$ \\
\hline \multicolumn{5}{|l|}{ Porosity } \\
\hline $\begin{array}{l}\text { Unsaturated hydraulic } \\
\text { conductivity }\end{array}$ & & $\mathrm{x}$ & $\mathrm{X}$ & \\
\hline $\begin{array}{l}\text { Saturated hydraulic } \\
\text { conductivity }\end{array}$ & & $\mathrm{X}$ & $\mathrm{X}$ & $\mathrm{X}$ \\
\hline Moisture retention & $\mathrm{X}$ & $\mathrm{X}$ & $\mathrm{X}$ & \\
\hline Chloride & & $\mathrm{X}$ & $\mathrm{X}$ & \\
\hline Pore water extraction for $\mathrm{H}^{3}$ & & & $\mathrm{X}$ & \\
\hline Groundwater Composition & & & & $\mathrm{X}$ \\
\hline Aquifer Testing & & & & $\mathrm{X}$ \\
\hline
\end{tabular}

'Section 4.1.2.3.4, Reidel et al. (1995), and revised by Kaplan (1997).

${ }^{2}$ Section 4.1.2.1, Reidel et al. (1995), and revised by Khaleel (1997).

${ }^{3}$ Section 4.1.2.3.3, Reidel et al. (1995), and revised by Murphy (1997).

${ }^{4}$ Section 4.1.3, Reidel et al. (1995).

\subsubsection{Locations and Activities}

There were three characterization wells drilled and sampled at the ILAWDC location. B8500 was drilled and sampled to $480 \mathrm{ft}$ BLS and was subsequently completed as a groundwater monitoring well with the screened interval spanning the 326 to $358 \mathrm{ft} \mathrm{BLS} \mathrm{zone.} \mathrm{The} \mathrm{other} \mathrm{two}$ borings at this location (B8501 and B8502) were drilled and sampled to $50 \mathrm{ft}$ BLS and were subsequently abandoned. The correlation deployment at the ILAWDC characterization site described in Section 3.2.1 above is planned to begin August 4, 1998 and is presently planned to continue until December 31, 1998. During this time frame a number of actions are planned and 
the specific timing and order of completion of these actions has not been determined at this time. Activities planned during this deployment are:

- Installation of new safety legs on the platform.

- Complete grouting procedure development and personnel training (if required).

- Completion of acceptance verification for grout equipment.

- Installation of the MSP instrument system.

- Test MSP operation and performance.

- $\quad$ SSP and MSP procedure development testing.

- Test SSP operation and sample recovery and handling procedures.

- Test $M / I$ operation and performance.

- MSP, SSP and M/I probe design and operation acceptance verification.

- Verify procedure for accurate platform placement with crane placement.

- Testing of the pipe cleaning and contamination control equipment and operations (if required).

- Complete a probe deployment using all applicable Special Work Permit (SWP) requirements.

- An additional deployment and testing of an in situ air permeameter device is being considered at this time. The timing and exact nature of the scope of these tests has not been outlined.

At the conclusion of the data gathering phase of the deployment, an instrument performance review and correlation of the CPP data to ILAWDC derived characterization data will be undertaken. Waste Management Federal Services, Inc., Northwest Operations (WMNW) and Dr. R. Randall will perform the comparison in an effort to provide HTI with a defensible and technically sound decision format to guide hole closure and grouting strategy. This strategy will be based on the guidance set forth in Grouting Guidelines for Hanford Tank Initiative Cone Penetrometer Borings prepared by Dr. Kevin Lindsey of D. B. Stephens and Associates. Dr. Lindsey prepared this guidance in response to a Washington State Department of Ecology (Ecology) letter dated February 2, 1998 from the Nuclear Waste Program, Stan Leja to Mr. Craig West of the U.S. Department of Energy (DOE). In this letter, Mr. Leja outlined the objectives and technical requirements which are set forth in the Washington Administrative Code (WAC) which are applicable to reporting and tracking of boreholes, hole closure and grouting requirements and actions which Ecology require before an approval to proceed would be granted. 
Prior to demobilization from ILAWDC and movement into AX tank farm a complete servicing of all the equipment will be undertaken to reduce operational difficulties and potential costs which would be incurred for undertaking maintenance activities inside the farm boundaries. Additionally, the platform will be prepared for deployment into the AX tank farm by steam cleaning the platform, push rods, tools, and support equipment.

\subsection{TANK AX-104}

\subsubsection{Background}

Tank AX-104 has been selected as a deployment site for demonstration of the characterization and sampling capabilities of the CPP. AX tank farm and AX-104 in particular were selected as a deployment site to provide support for characterization and tank closure assessments. Figures 6 and 7 are maps of the AX tank farm and the projected contaminate plumes in the subsurface adjacent to tank AX-104 (Figure 8). Information gathered from CPP tool investigations could potentially provide useful information relating to waste inventory and clean-up evaluations and would be utilized in tank closure action plans.

\subsubsection{Locations and Activities}

Three areas ("windows") clear of subsurface obstructions have been identified as potential push sites adjacent to AX-104 (see Figures 9, identifying the location of the "windows" overlain on a composite tank farm infrastructure map, and Figure 10, GPR data gathered around AX-104). These sites were selected for Excavation Permit approval by review of existing tank farm construction information, interpretation of GPR data gathered in the area, consideration of existing surface obstructions, and assessment of potential information gained from the subsurface for comparison to projected contaminate levels. The required Hanford Site Excavation Permit and other pre-activity documentation (e.g. Tank Farm Work Control Package, Special Work Permit, etc.) will be obtained for the deployment in AX farm. A specific approach has been utilized to compile data to identify potential points for interrogation and to support the final selection of the sites.

Following is the list of actions utilized to identify possible penetrometer deployment points within AX tank farm and the process followed to select and verify the deployment points.

1. Site inspections and drawings reviews identified areas that had no apparent obstacles/impediments to safe operation (see Table 2 for listing of drawings reviewed). Completed.

2. The applicable drawings of selected target areas were compared to projections of known, or estimated contaminate plumes. Areas with discernable surface and sub-surface obstructions were rejected. Completed. 
ES-RPT-001 Rev. 0

Rev. 0

Figure 6. AX Tank Farm Location Map.

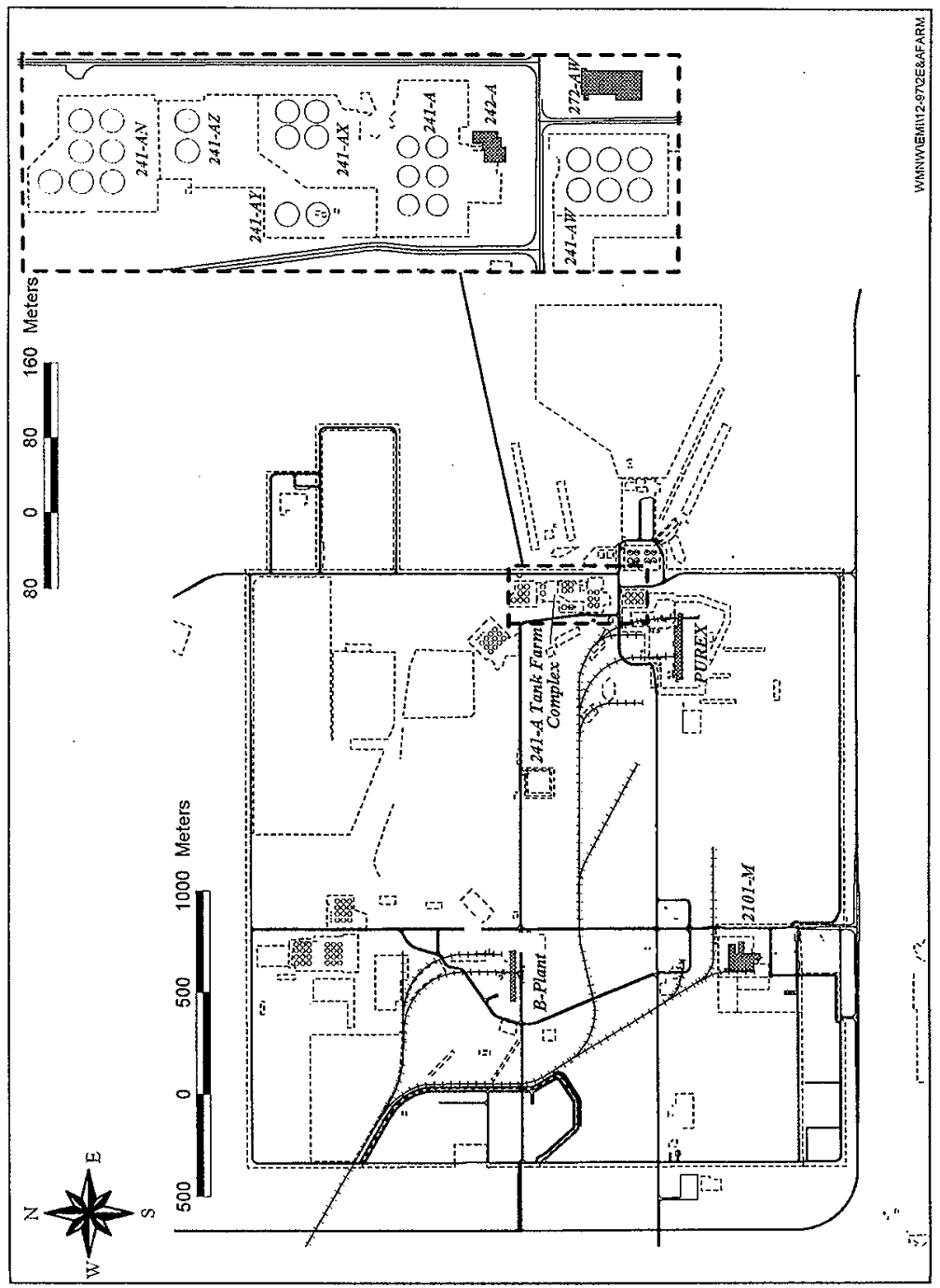




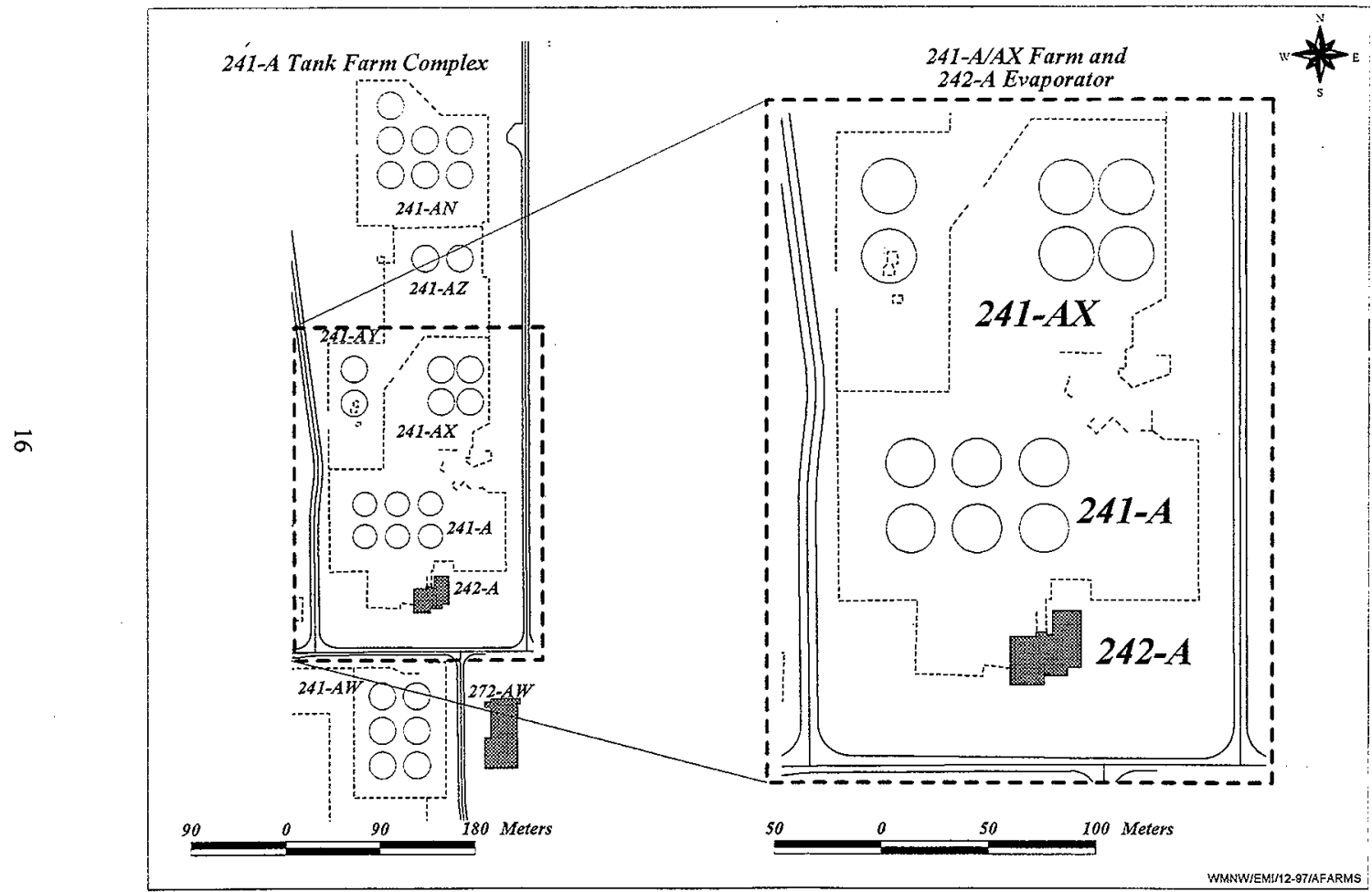

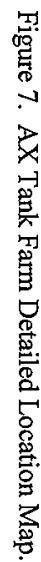


ES-RPT-001 Rev. 0

Figure 8. Estimated Plumes for AX Farm.

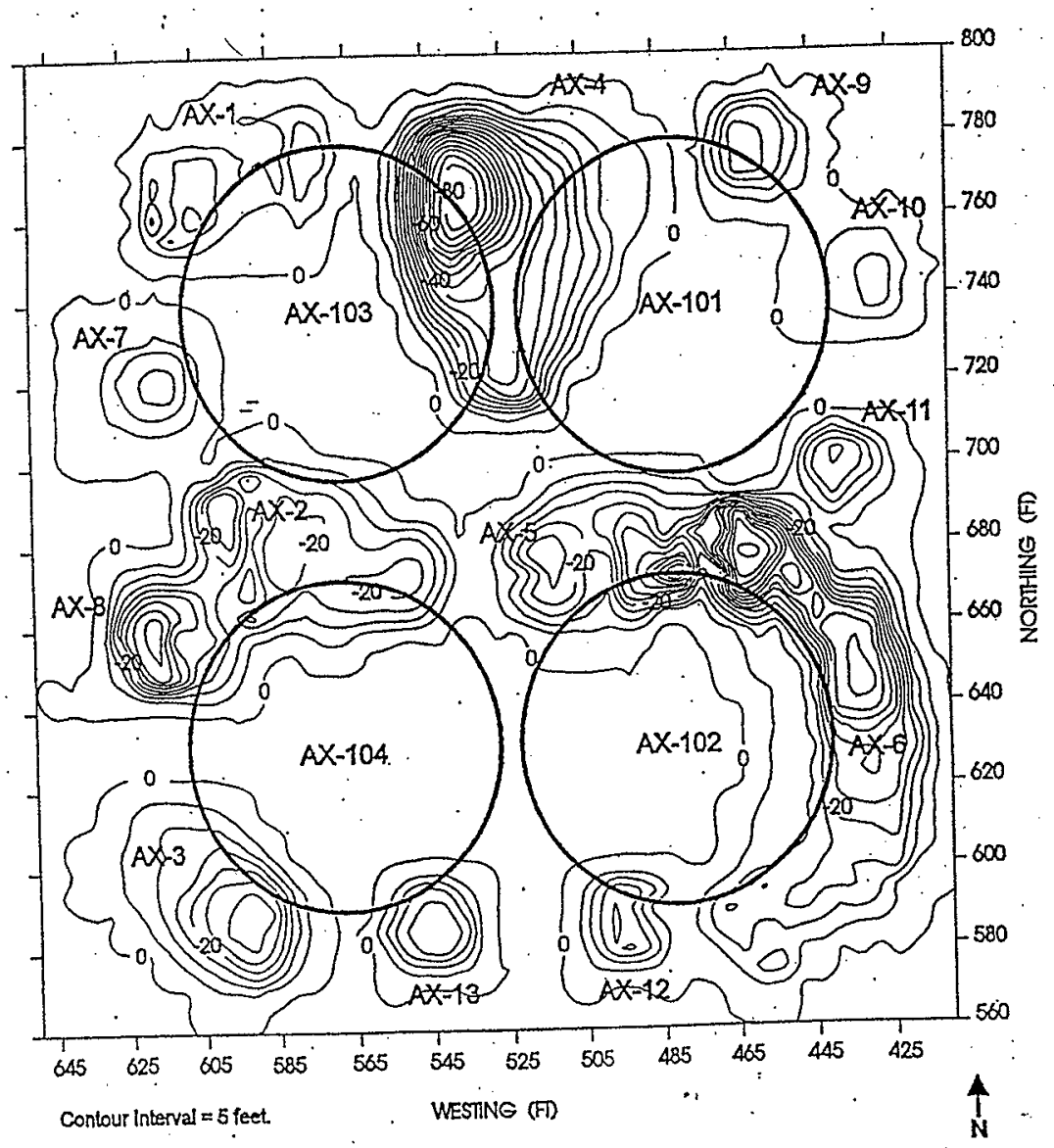


ES-RPT-001 Rev. 0

Rev. 0

This page intentionally left blank. 


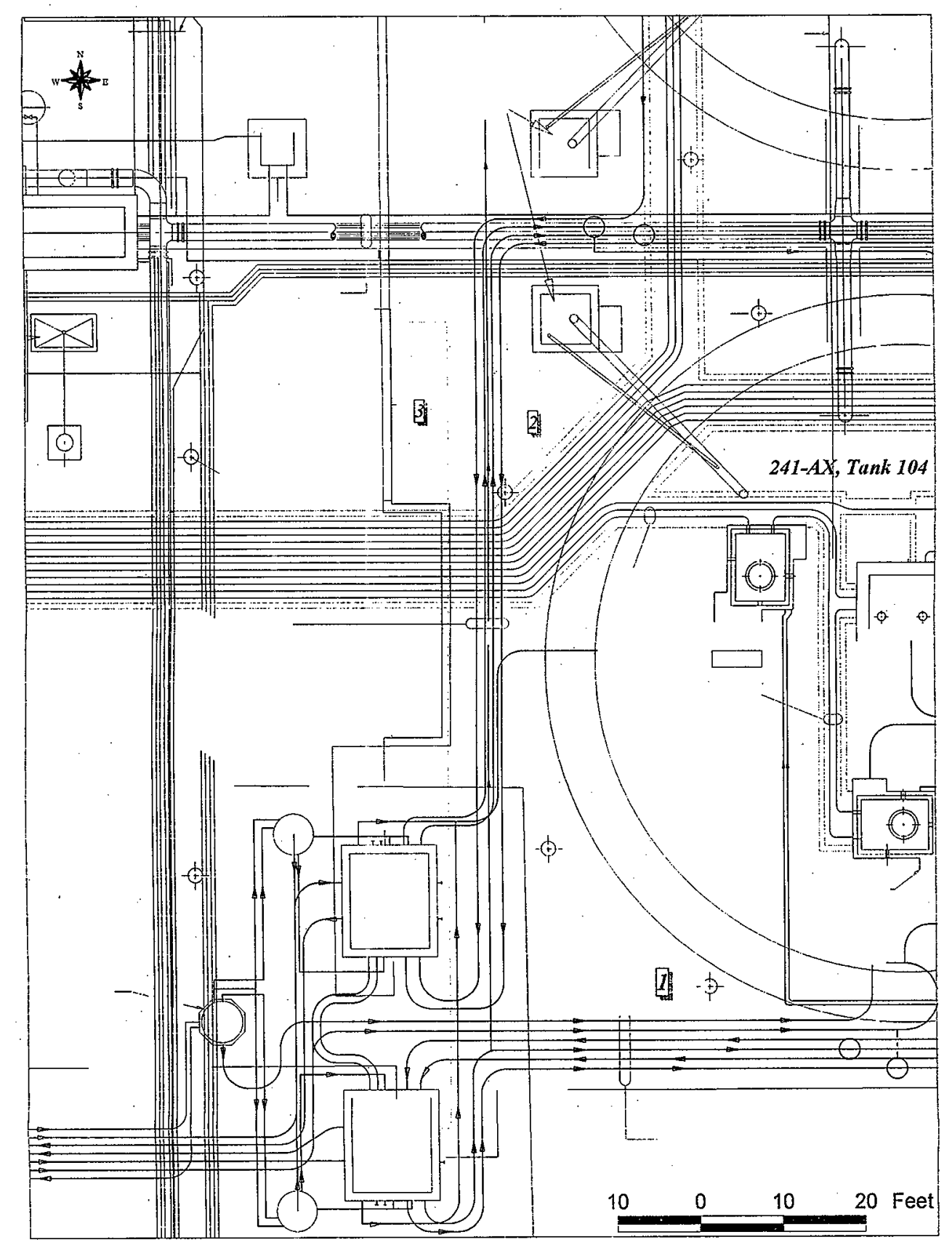




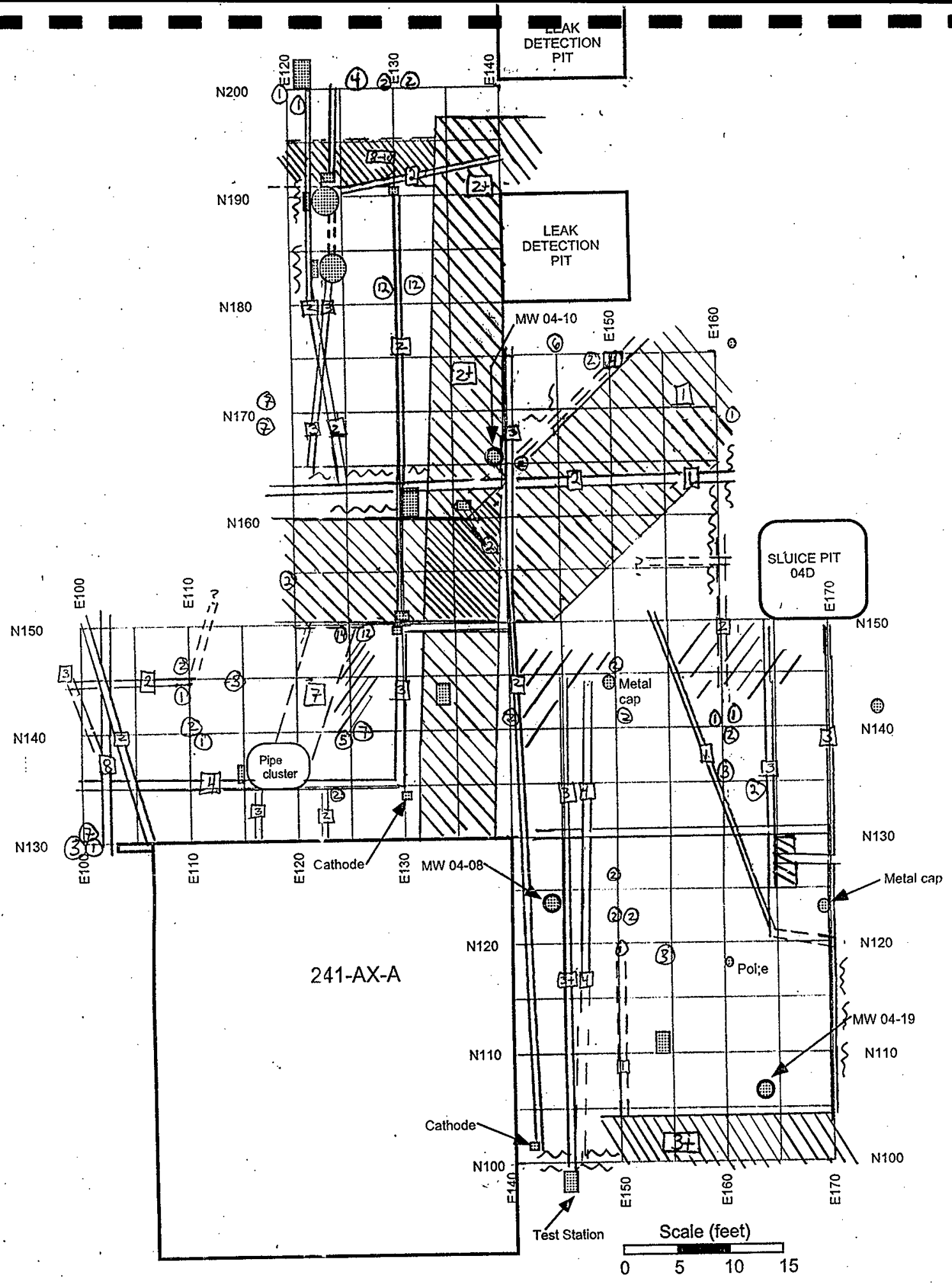

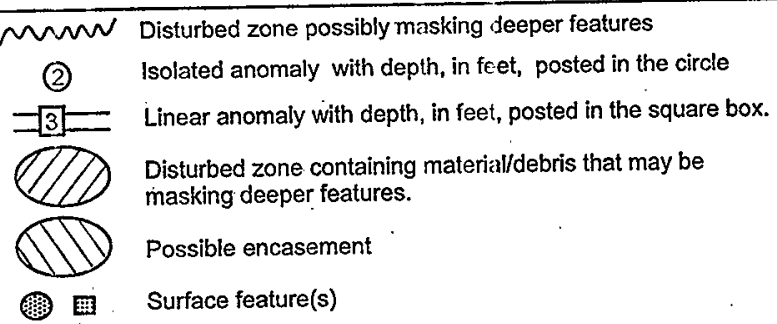

Questions: Contact TH Mitchell / KA Bergstrom @ 372-9591 CH2MHill

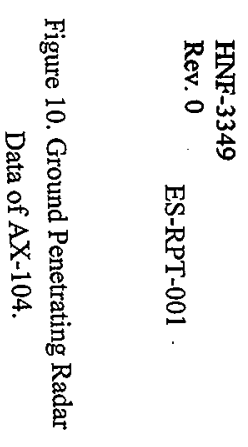

Ground Penetrating Radar Investigation Tank AX-104, 200 East, 3/25/98

Waste Management Federal Services 


\section{ES-RPT-001 Rev. 0}

Table 2. Reviewed Drawings.

\begin{tabular}{|l|l|l|}
\hline \multicolumn{1}{|c|}{ Reference Number } & \multicolumn{1}{c|}{ Description } & \multicolumn{1}{c|}{ Remarks (if applicable) } \\
\hline H-2-44501, Sheet 69 & 200 East Area Map & A Plant Facilities \\
\hline H-2-443618 & Direct Buried Piping & \\
\hline H-2-44619 & Direct Buried Piping & \\
\hline H-2-44629 & General Piping & \\
\hline H-2-44725 & AX-801 A \& B Elec & \\
\hline H-2-44711 & Underground Cable Runs & \\
\hline H-2-63843 & Piping Tank-104-AX & \\
\hline H-2-68240 & 104-AX Tank Arrangement As-built & \\
\hline H-2-73373 & AX Piping Isolation & \\
\hline H-2-73382 & Piping Tank Isolation AX-104 & \\
\hline H-2-91126 & Elec/Inst. Distribution Plan 241-A/AX & \\
\hline H-2-820817, Sheet2 & TMAC-AX-TF Conduit Runs & \\
\hline H-2-69156 & Essential Elec. Pwr. \& Inst. 241-A/AX & \\
\hline H-2-73842 & Piping Plan 241-AX & \\
\hline H-2-69157 & Elect. Heat Trace Plans & Identical to H-2-91126 \\
\hline H-2-44711 & Elect. TF Power UG Cable Runs & \\
\hline
\end{tabular}

3. The potential sites were staked and located with Global Positioning System (GPS) for precise referencing, and for correlation points with the GPR information. Completed.

4. Conduct GPR scans and review data for anomalies which correspond to known obstructions and adjust push areas to avoid questionable GPR responses which do not correspond to mapped structures. Completed.

5. Select new locations within the area adjacent to $\mathrm{AX}-104$ and review new locations relative to GPR and mapped structures. Locate with GPS system. Completed.

6. Input tank loading calculations for selected sites as per tank farm requirements. These load calculations will take into account the crane and platform weights for total load calculations for dome loading requirements and are a portion of the tank farm generated Work Control Package (WCP). Waiting for completion based on TBD WCP completion date. 


\section{ES-RPT-001 Rev. 0}

7. Modify selected sites, if required by tank loading calculations to meet approval limits (if required). TBD.

8. Prepare finalized site list with diagrams, maps, scan summaries and data for inclusion in the Work Plan and for use with the required Site Excavation Permit. Underway, planned for completion by September 30, 1998.

9. At the conclusion of the sign-off process for the Excavation Permit and WCP, a GPS system will be utilized to identify the exact location of the push window targets for platform location purposes. Scheduled for December 1998.

The Figure 9 has a listing in the upper right hand corner of all of the applicable tank farm drawings that have been include in the preparation of the composite drawing. Three sites that have been determined to have no anomalies in GPR screening and are clear of any mapped tank farm underground obstructions are marked as Sites 1,2, and 3 on Figure 9. Comparison to the provided contaminate plume maps indicates that these sites can potentially provide significant stratigraphic and contaminate information.

3.3.2.1 Deployment Steps. As indicated above, preliminary planning and data gathering for acquiring the necessary permits for deployment in $\mathrm{AX}$ are underway. This planning and permitting includes, but is not limited to:

- Excavation Permit.

- Obtaining a tank farm approved WCP.

- Providing the documentation outlined on the Drilling Planning Form.

Because of the complex nature of movement within the tank farm an outline of the steps and actions which will be followed to move equipment into and around the farm for placement on the selected push locations has been prepared. The following steps are the outline of the procedural actions to provide for platform movement within the AX farm:

1. The CP platform and associated equipment (e.g. leg extenders, ballast, spreader bar, etc.) will be placed on regulated trailers for movement into the farm.

2. The trailers will be moved through the Southeast Gate of A Farm and placed at the south side of AX by way of the route outlined on Figure 11.

3. At this time it is estimated that one lift, utilizing a 55 ton crane, will be required to remove and place the platform from the trailer to the selected point in Site 1 (see Figure 9, Site 1 for potential platform location and Figure 11 for crane location at the time of placement).

4. The platform will be made operational and characterization and data gathering activities will be conducted. 
ES-RPT-001 Rev. 0

Figure 11. Crane Locations for Placing Platform.

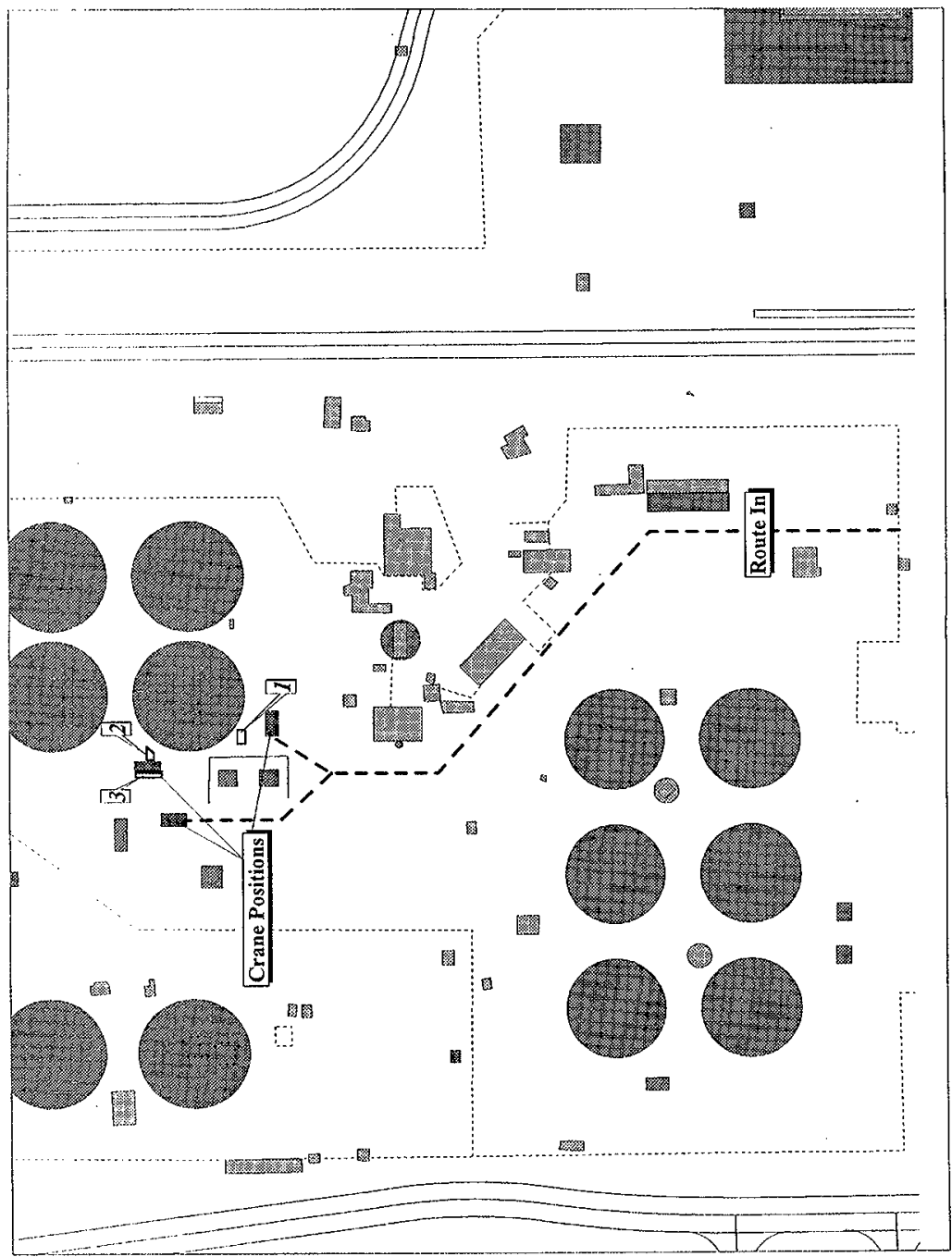


5. If more than one location in $\mathrm{AX}$ area is selected for interrogation, the crane will be repositioned and the platform will be placed at the new push site (e.g., Site 2 or Site 3 ). If necessary, the platform will be reloaded on to a trailer and moved to a position where the crane can place the platform for interrogation of the next selected "window" (e.g., Site 2 or Site 3).

6. It is planned that a minimum of two lifts will be required to move the platform from the trailer to the desired location over Site 2. These pick points are depicted on the enclosed map.

7. At the conclusion of activities in $\mathrm{AX}$ the crane will be repositioned to place the platform and support equipment on the trailers for removal from the farm.

3.2.2.2 Schedule of Deployment Activities. Entry into AX farm is tentatively scheduled for January 7,1999 to perform the first CP push. The total number of penetrations at the first selected site will be determined by the available operational time and project objectives (e.g., number of soil samples, MSP data needed, etc.) and have not been determined at this time. The total deployment operational time to interrogate all the locations is projected to require approximately 2-3 months. A more detailed schedule of activities to be performed will available from the project management as soon as the operation framework and budget have been determined.

\subsection{REFERENCES}

Daniel B. Stephens \& Associates, Inc., 1998, Grouting Guidelines for Hanford Tank Initiative Cone Penetrometer Borings, (Prepared for Waste Management Federal Services, Inc., and Numatec Hanford Corporation), Daniel B. Stephens \& Associates, Inc., Albuquerque, New Mexico, January 2, 1998.

Kaplan, D. I., 1997, Test Plan for Performing Kd Measurements on Borehole \#1 Samples:

Subtask 1A in Project ED8029, Draft Letter Report, Pacific Northwest National Laboratory, Richland, Washington.

Khaleel, R., 1997, Test Plans for Measurement and Analysis of Vadose Zone Hydraulic Properties for the Tank Waste Disposal Site, FDNW-ENI-98-008, Fluor Daniel Northwest, Inc., Richland, Washington.

Leja, Stan, 1998, Installation of Cone Penetrometer Boreholes at the Hanford Site, (Letter to Craig West, U.S. Department of Energy, February 2), Washington State Department of Ecology, Kennewick, Washington.

Murphy, E. M., 1997, Tracer Measurements of Samples from Shallow Boreholes, Letter Report, Pacific Northwest National Laboratory, Richland, Washington. 
Reidel, S. P., and K. D. Reynolds, 1998, Characterization Plan for the Immobilized Low-Activity Waste Borehole, PNL-1 1802, Pacific Northwest National Laboratory, Richland, Washington.

Reidel, S. P., A. M. Tallman, V. G. Johnson, C. J. Chou, S. M. Narbutovskih, and J. Kiesler, 1995, Characterization Plan for the Proposed TWRS Treatment Complex, WHC-SD-WM-PNL-109, Westinghouse Hanford Company, Richland, Washington. 


\section{DISTRIBUTION SHEET}

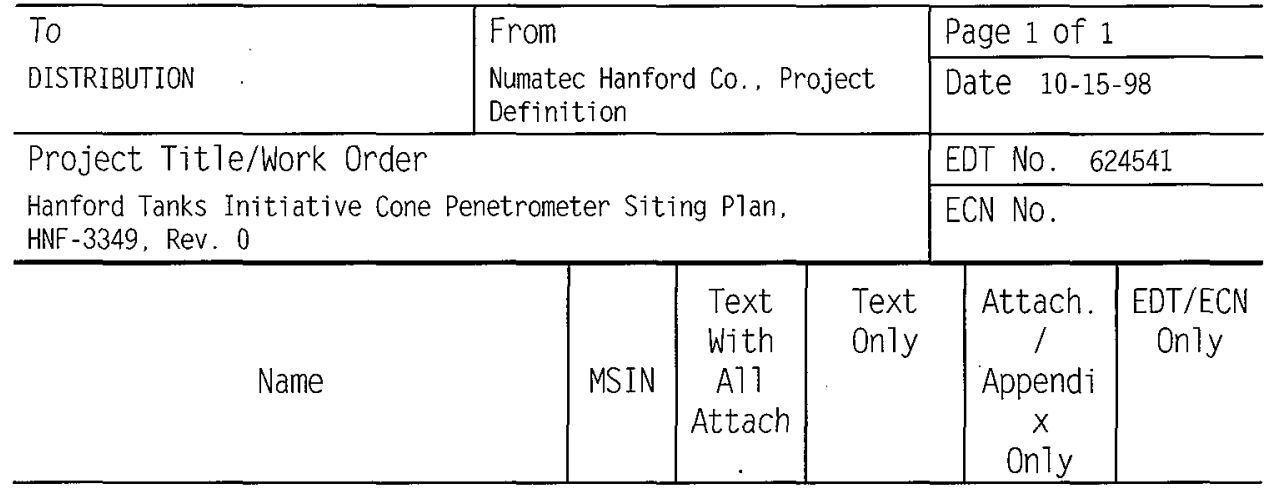

CENTRAL FILES

PROJECT FILES - HTI

DOE/RL READING ROOM

JJ Huston

WJ Kennedy

GL Troyer

DA Bragg

WS Callaway

DF Iwatate

DB Hagmann

$R$ Root

AF Noonan

GP Janicek

DD Wanner

JS Schofield

JG Kristofzski

DL Banning
B1-07

R1-41

H2-53

R2-89

S7-03

T6-50

S5-05

\$3-90

R2-89

R2-89

R2-53

R2-89

S7-12

S7-12

$57-12$

S7-01

R2-12 $x$

$x$

$x$

$x$

$x$

$x$

$x$

$x$

$x$

$x$

$x$

$x$

$x$

$x$

$x$

$x$

$x$ 